\title{
14. Yabancı dil olarak Türkçe öğretiminde yazma becerisi ve kazanım ilişkisi
}

\section{Ramazan ŞİMŞEK²}

\section{İlhan ERDEM3}

\begin{abstract}
APA: Şimşek, R.; Erdem, İ. (2021) Yabancı dil olarak Türkçe öğretiminde yazma becerisi ve kazanım ilişkisi RumeliDE Dil ve Edebiyat Araştırmaları Dergisi, (22), 267-279. DOI: 10.29000/rumelide.895762.
\end{abstract}

\section{Öz}

Yabancılara Türkçe öğretimi derin tarihsel kökeniyle birlikte 21. yüzyılın ilk çeyreğinde ivme kazanmış; küreselleşen dünyada Türkiye'nin son yllardaki siyasal ve toplumsal rolündeki pozitif değişimi ile yabancı dil olarak Türkçe öğrenen kişilerin sayısı da bariz bir şekilde artmıştır. Pozitif yönlü bu hareketlilik ve değişim doğal olarak yabancı dil olarak Türkçe öğretiminde kullanılan materyallerin sayısını ve niteliğini de etkilemiştir. Bu kapsamda yabancı dil olarak Türkçe öğretiminde ders kitaplarında çeşitlilik artmış; dijital ve basılı materyaller sürecin lokomotifi haline gelmiştir. Bu materyallerde temel dil becerilerine yönelik etkinliklerin niteliği sürecin verimliliği açısından büyük önem arz etmektedir. Yabancı dil eğitimi açısından anlamaya yönelik dil becerileri anlatmaya yönelik dil becerilerine göre daha kolay gelişmektedir. Anlatmaya dayalı yazma becerisi ise temel dil becerileri içinde gelişimi en zor beceri olarak değerlendirilmektedir. Ders materyallerin içinde bulunan etkinlikler temel dil becerilerinin gelişimini hızlandırma ve yapılandırma gayesi taşımalıdır. Bu çalışmada Yunus Emre Enstitüsü Türkçe Öğretimi B1 ders kitabı bünyesinde yer alan yazma etkinlikleri öğretmen kılavuz kitabında yer alan 52 adet yazma becerisi kazanımı ve CEFR B1 düzeyi yazma becerisi içeriği ekseninde kategoriler oluşturularak içerik analiziyle değerlendirilmiştir. Bu kapsamda yazma becerisi etkinliklerinin hangi kazanımları karşıladığı üzerinde durulmuş; ifade gücüne yönelik kazanımların ve içeriklerin öne çıktı̆̆ı tespit edilmiştir.

Anahtar kelimeler: Yabancılara Türkçe öğretimi, yazma becerisi, B1 düzeyi, etkinlik, ders kitabı

\section{Writing skills and acquisition relationship in teaching Turkish as a foreign language}

\begin{abstract}
Teaching Turkish to foreigners has gained momentum in the first quarter of the 21st century with its deep historical roots. Turkey has taken in recent years with political and social causes of migration and has increased markedly in the number of people who learn Turkish in this context. This positive mobility and change naturally affected the number and quality of the materials used in teaching Turkish as a foreign language. In this context, the variety of textbooks in teaching Turkish as a foreign language has increased; digital and printed materials have become the engine of the process. The quality of the activities for basic language skills in these materials is of great
\end{abstract}

Bu çalışma 2-4 Kasım 2017 tarihleri arasında gerçekleştirilen IX. Uluslararası Dünya Dili Türkçe Sempozyumunda sunulan bildirinin genișletilmiş halidir.

Dr. Öğr. Gör., Nevşehir Hacı Bektaş Veli Üniversitesi, TÖMER (Nevşehir, Türkiye), ramazansimsek@nevsehir.edu.tr, ORCID ID: 0000-0002-8295-8903 [Araştırma makalesi, Makale kayıt tarihi: 16.01.2021-kabul tarihi: 20.03.2021; DOI: 10.29000/rumelide.895762.]

Prof. Dr., İnönü Üniversitesi, Eğitim Fakültesi, Türkçe ve Sosyal Bilimler Eğitimi Bölümü, Türkçe Eğitimi ABD (Malatya, Türkiye), ilhan.erdem@inonu.edu.tr, ORCID ID: oooo-0002-4244-6225

Adres $\mid$ Address

RumeliDE Dil ve Edebiyat Araştırmaları Dergisi $\quad$ RumeliDE Journal of Language and Literature Studies Osmanağa Mahallesi, Mürver Çiçeği Sokak, No:14/8 $\quad$ Osmanağa Mahallesi, Mürver Çiçeği Sokak, No:14/8

Kadıköy - İSTANBUL / TÜRKIYE 34714 Kadıköy - ISTANBUL / TURKEY 34714 e-posta: editor@rumelide.com

e-mail: editor@rumelide.com,

tel: +90 505 7958124, +90 216773 o 616 phone: +90 505 7958124, +90 2167730616 


\begin{abstract}
importance for the efficiency of the process. In terms of foreign language education, language skills for understanding develop more easily than language skills for expression. The narrative writing skill is considered to be the most difficult skill to develop among basic language skills. The activities in the course materials should aim to accelerate and structure the development of basic language skills. In this study, the writing activities included in the Yunus Emre Institute Turkish Teaching B1 textbook were examined on the axis of 52 writing skill acquisitions in the teacher's guide book and CEFR B1 level writing skills content. In this context, the achievements of writing skills activities were emphasized. In this context, the achievements of writing skills activities were emphasized; It was determined that the achievements and contents regarding expressive power stand out.
\end{abstract}

Keywords: Teaching Turkish to foreigners, writing skill, B1 level, activity, textbook

\title{
Giriş
}

Tarihsel süreç içerisinde doğrudan ya da dolaylı olarak iletişim kuran insanoğlunun en büyük bildirişim aracı dildir. Dil, insanların düşündüklerini ve duyduklarını bildirmek için kelimelerle veya işaretlerle yaptıkları anlaşma, lisandır (Türkçe Sözlük, 2005: 526). Dil, bir toplumda düşünce duygu ve isteklerin ses ve anlam yönünden ortak olan öğeler ve kurallardan yararlanılarak başkalarına aktarılmasını sağlayan çok yönlü, çok gelişmiş bir dizgedir (Aksan, 1977: 55).

Dil eğitimi iletişimsel süreçler açısından alıcı ve verici dil becerilerini bünyesinde barındırmaktadır. Dinleme ve okuma becerileri alıcı beceriler olarak kabul görürken konuşma ve yazma becerileri verici beceriler olarak değerlendirilmektedir. Temel dil becerilerinin birbiri ile etkileşimi bu becerilerin birbirini bütünlediğini, desteklediğini göstermektedir.

Üzerinde onlarca tanım yapılan "dil” kavramı özelinde anadili dışındaki diller ilk çağlarda siyaset, ticaret, kültür vb. sebepler ile seçkin topluluklar tarafından öğrenilirken 20 ve 21. yüzyılda küçük bir köy haline gelen dünya ile son derece geniş kitlerle buluşmuş ve yabancı dil öğrenimi önemli bir ekonomik sektör haline gelmiştir (Erdem ve diğerleri, 2015, 460).

200o'li ylllardan sonra Ortadoğu coğrafyasında oluşan demografik hareketler ve Türkiye'nin izlediği "insan" odaklı yaklaşım ile siyasi, ekonomik ve sosyal açıdan problem yaşayan tüm etnik grupların ilgi odağının Türkiye ve Türkçe olduğu görülmektedir. Bu ilgi kapsamında ülkemizde artan yabancı sayısı ile Türkçe öğrenen yabancı sayısı da aynı oranda artmıştır. Böylece Türkiye ve Türkçe eğitim odaklı bir şemanın merkezine konumlanmıştır.

Temel dil becerileri ekseninde verilen yabancı dil eğitimi için kullanılan eğitim araçları ve materyaller sürecin mihenk taşları içinde yer almaktadır. Yabancı dil olarak Türkçe öğretimi sürecinde öğretmen ve öğrenciler açısından en çok kullanılan araç ders kitapları ve yardımcı kitaplardır. Ders kitapları yabancı dil eğitimi boyunca öğrenciye de öğretmene de rehberlik ederek bir program çerçevesinde dilin aşama aşama öğretimini üstlenir. Bu kapsamda yabancı dil eğitiminde temel dil becerilerini bir plan ve program dâhilinde geliştirmek esastır.

Türkçenin yabancı dil olarak öğretimi bir süreç olarak ele alındığında öğrenciler arasında öğrenilmesi en zor becerinin yazma becerisi olarak ifade edildiği kanıksanmış bir gerçektir. Karababa (2009:276), Türkçeyi yabancı dil olarak öğrenenlerin gereksinimlerine, düzeylerine, çeşitliliğine uygun ders öğretim araç-gereçleri ve ders kitaplarının yeterli olmadığını ifade etmektedir. Araç gereç gereksinimleri ve bu araç gereçlerin nitelik bakımından yetersizlikleri Türkçenin yabancı dil olarak 
öğretiminde karşılaşılan temel sorunları teşkil etmektedir. Ayrıca yazma becerisi açısından "en zor beceri” önyargısı ile temel sorunlar birleşince var olan olumsuzlukların katlanarak artması kaçınılmaz bir durumdur.

Yabancı dil eğitimi açısından rehber hükmünde olan Avrupa Ortak Diller Başvuru Metni ders kitabı hazırlayan komisyonların kitap bünyesindeki metinlerin, etkinliklerin, sözcüklerin öğrencinin günlük hayat içinde kullanabileceği şekilde olması gerektiğini belirtmiş; temel dil becerilerinin fonksiyonel olarak kullanılması ve birbirini destekleyici nitelikler barındırması hususunu vurgulamıştır. $\mathrm{Bu}$ hususlar gözetildiğinde yabancı dil eğitiminde kullanılan materyal bünyesinde barındırdığı etkinlikler, metinler, dilbilgisi yapıları, söz varlığı açısından temel dil becerilerini desteklemelidir. Bu çalışmada da yazma becerisi etkinlikleri ve kılavuz kitaptaki yazma becerisi kazanımları ele alınacaktır.

\section{Yazma becerisi ve yabancı dil eğitimi ilişkisi}

Yazma insanoğlunun düşünce, duygu, durum ve çeşitli taleplerini bir takım sembollerle ifade etme eylemi olarak tanımlanabilir. Yazılı olarak kendini ifade eden insanoğlu bu sayede toplumsal, kültürel, sosyal açıdan birikimini kalıcı hale getirmiştir. Tarihsel süreç içinde toplumsal etkileşimi hızla artan toplumlar ikinci dille de kendini yazılı olarak ifade etme gereksinimi hissetmiştir. Hughey (1983) ikinci dilde yazmanın avantajlarını dört maddede ifade etmiştir:

- Yazma iletişimin önemli bir yoludur.

• Yazma eleştirel düşünme ve problem çözme içindir.

- Yazma kişinin kendini yenilemesidir.

- Yazma kişisel çevremizi kontrol etmede bize yardımcı olur

Başta ifade edildiği gibi ülkemizde Türkçeyi yabancı dil olarak öğrenen kişilerin çok büyük kısmının öğrenci olduğu düşünüldüğünde yazma becerisinin önemi bir kat daha artmaktadır. Bu kapsamda akademik başarı açısından sınavların önemi ve yazma becerisindeki yetkinlik öğrenci için eğitim hayatı bakımından önemlidir. Hughey (1983), ikinci bir dili öğrenen öğrencilerin yazma yeterliliği gösterene kadar ikinci dillerinde tam okuryazarlığı asla elde edemeyeceklerine inandırılmaya ihtiyaçları olduklarını ifade etmiştir. Özetle yazma becerisi yabancı dil eğitiminde tam anlamıyla yetkinliğin kazanıldığı beceri olarak nitelenebilir. Bu kapsamda da Türkçeyi yabancı dil olarak öğrenen öğrenciler akademik başarı ve yetkin bir Türkçe kullanımı için yazma becerisi üzerinde özel bir çaba göstermeleri için yönlendirilebilir. Alan yazında yapılan birçok çalışma yabancı dil olarak Türkçenin öğretiminde yazma becerilerinin oldukça sorunlu bir alan olduğunu göstermektedir. Yapilan çalışmalar öğrencilerin en çok yazma becerilerinde sorun yaşadıklarını ortaya koymaktadır (Açık, 2008; Kara 2009; Köse 2010; Tiryaki, 2013; Çangal, 2020). Köse (2010)'nin çalışmasında öğrenciler, diğer beceri alanlarından farklı olarak yazma alanında \%75 oranında "yapamam" ifadesini seçmişlerdir. Açı (2008)'ın yaptığı araştırmada ise öğrencilerin yazma alanında yaşadıkları sorunun boyutu ortaya konmaya çalışılmıştır. Öğrenciler, ilk sırada \% 58.95 ile "bazen”, ikinci sırada \% 26 ile "hiç", üçüncü sırada \% 14 ile "sık sık" şeklinde cevap vermişlerdir. Dolayısıyla öğrencilerin yaklaşık olarak \% 73’ü yazma becerileri alanında sorun yaşadığı ortaya çıkmıştır. Yaşanan bu sorunlar benimsenen yaklaşım ve yöntemlere de doğrudan ilintili olduğu söylenebilir.

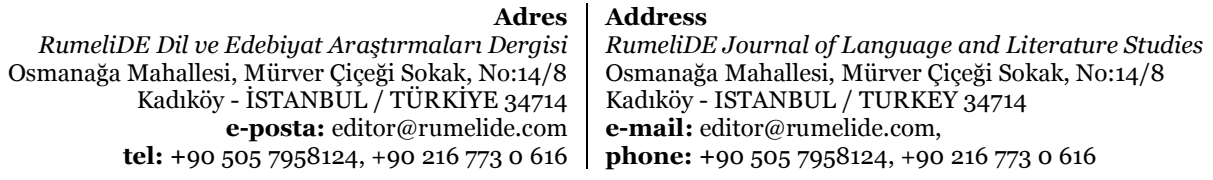

tel: +90 505 7958124, +90 2167730616 
Yabancı dilde yazma etkinliklerinde kullanılan yöntemler, süreçler oldukça çeşitlidir. Yazma alanında öğretim sürecini iki ayrı aşamada düşünmek gerekir: Kazanım ve geliştirme. Kazanım aşaması temel bilgilerin öğrenilmesi ve becerilerin kullanılabilecek düzeyde elde edilmesiyle ilgilidir. Yazma açısından düşünürsek, harflerin, hecelerin, kelimelerin ve cümlelerin ne olduğunun ve nasıl yazılacağının öğrenilmesi kazanım aşamasıyla ilgilidir. Diğer taraftan kazanılan becerilerin etkili bir yazılı anlatımda nasıl kullanılacağının öğrenilmesi gelişim aşamasıyla ilgilidir (Akyol, 2006: 93). Raimes (1983), ikinci dil yazma çalışmalarında resimlerden yararlanma, tablo, grafik ve şemalardan yararlanma, haritalardan yararlanma, kopyalama, bağdaşıklık çalışmaları, yazım ve noktalama çalışmaları, cümle düzenleme çalışmaları, özetleme, tamamlama(kelime, cümle ya da paragraf), yorumlama, tepki verme, beyin firtınası, not tutma, kontrollü yazma, güdümlü yazma gibi yöntemleri açıklamaktadır. Anılan yöntemlerde öğrenci seviyesi esas alınmıştır. Basit dikte, kopyalama cümle düzenleme etkinliklerinin temel düzeylerde; kompozisyon ve tematik yazma etkinliklerinin ise daha ileri düzeylerde kullanılabileceği ifade edilmiştir. İmla kuralları ve noktalama işaretleri ise her seviyede öğrencilere aktarılması gereken bir konu başlı̆̆ıdır. Bu sıralama ışı̆ında öğrencilere kolaydan zora doğru giden bir sıralama ile yama etkinlikleri yaptırılabilir. Yaratıcı yazma ve tasvir etkinlikleri ise ileri düzey öğrencileri için kullanılabilir. Anlaşılacağı üzere öğrencinin seviyesinin gözetilmesi yabancı dilde yazma becerisi için olmazsa olmaz kıstaslar içinde yer almaktadır. Öğrencinin seviyesinin üzerinde bir yazma etkinliği ile öğrencinin dil öğrenme motivasyonu düşeceği gibi kendine olan güveni de sarsılacaktır. Bu sebeple yazma etkinliklerinin seviyesi, hangi zihinsel ve iletişimsel becerileri edindirdiği oldukça önemlidir. Bu değerlendirmeler bağlamında yabancı dil olarak Türkçe öğretiminde kullanılan Yunus Emre Enstitüsü B1 düzeyi ders kitabının yazma etkinlikleri belirli kıstaslar çerçevesinde değerlendirilecektir.

\section{Yöntem}

\section{1.Çalışmanın deseni}

Bu çalışmada nitel araştırma yöntemi benimsenmiştir. Nitel araştırma "gözlem, görüşme ve doküman analizi gibi nitel veri toplama tekniklerinin kullanıldığı, algıların ve olayların doğal ortamda gerçekçi ve bütüncül bir biçimde ortaya konmasına yönelik nitel bir sürecin izlendiği araştırma" olarak tanımlamak mümkündür (Yıldırım ve Şimşek, 2008, s.39). Araştırmanın verileri doküman incelemesi yoluyla toplanmış; analiz sürecinde ise içerik analizi tercih edilmiştir. İçerik analizi yoluyla veriler tanımlanmaya çalışılır; birbirine benzediği ve birbiri ile ilişkisi olduğu tespit edilen veriler belirli kavramlar ve temalar çerçevesinde bir araya getirilerek yorumlanır (Altunışık, Coşkun, Bayraktaroğlu, 2010:302). Araştırma kapsamında kazanımlar kategorize edilmiş ve yorumlanmıştır.

\subsection{Sinırlılık}

$\mathrm{Bu}$ araştırma, başta Yunus Emre Enstitüsü temsilciliklerinde ve Türkçe Öğretim Merkezlerinde kullanılan B1 düzeyindeki Yunus Emre Enstitüsü Türkçe Öğretimi ders kitabı yazma becerisi etkinlikleri ile sınırlandırılmıştır.

\subsection{Verilerin analizi}

Yunus Emre Enstitüsü B1 düzeyi ders kitabında yer alan yazma etkinlikleri yayın bünyesinde yer alan kazanımlar ile karşılaştırılmış; akabinde ise CEFR'de ilgili düzeyde yer alan kıstaslara uygunluğu

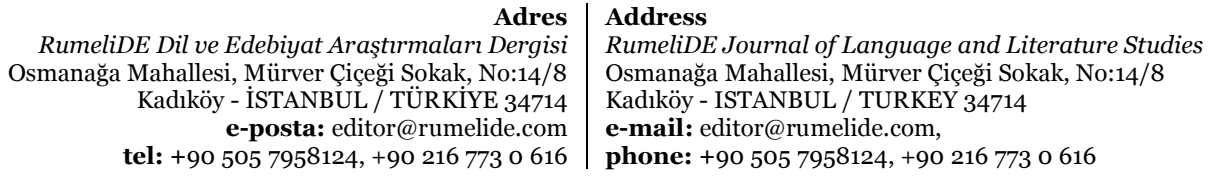

RumeliDE Dil ve Edebiyat Araşttrmaları Dergisi -posta: editor@rumelide.com tel: +90 505 7958124, +90 2167730616
Address

Osmana

e-mail: editor@rumelide.com

phone: +90 5057958124, +90 2167730616 
bakımından karşılaştırılarak değerlendirilmiştir. Son aşamada yazma becerisi etkinlikleri içeriklerine göre kategorize edilmiş ve bu kapsamda analiz süreci yürütülmüştür.

\subsection{Geçerlik ve güvenirlik}

İçerik analizi yöntemi ile yapılan incelemelerin güvenirliğinin belirlenmesi için çeşitli yollara başvurulur ve bu yollardan biri de aynı araştırmacının farklı zamanlarda aynı materyali tekrar kodlaması ve kodlamalar arasındaki tutarlığın hesaplanmasıdır. Bu çalışmada gerçekleştirilen içerik analizinin güvenirliğini belirlemek için ders materyalinde yer alan yazma becerisi kazanımları ve etkinlikleri analiz edilerek kategorize edilmiş, kodlanmıştır. Bu süreçte uzman görüşü de alınmıştır. Araştırma örnekleminde yer alan yazma becerisi kazanımları ve etkinlikleri iki araştırmacı tarafından çözümlenmiş, kodlanmış ve incelemeler arası tutarlılık, uyuşum yüzdesi formülü kullanılarak hesaplanmıştır (Stemler, 2001; Tavşancıl ve Aslan, 2001).

$$
\text { Güvenirlik }=\frac{\text { Uzlaşma Sayısı }}{\text { Uzlaşma }+ \text { Uzlaşmama Sayısı }}
$$

Formül 1. Kodlayıclar/ Kodlamalar Arası Tutarlılık Hesaplaması

Yapılan kodlamalar arası uyuşumun belirlenmesinde Formül 1 kullanılmış ve iki kodlama arasındaki uyuşum 0.88 olarak bulunmuştur. Elde edilen sonucun 0.70 'ten yüksek olması kabul edilebilir bir uyuşma düzeyi anlamına geldiğinden (Tavşancıl ve Aslan, 2001) incelemeler arası uyuşumun var olduğu, bir diğer ifadeyle bu yöntem için kabul edilebilir düzeyde güvenirliğin sağlandığı sonucuna ulaşılmıştır.

\section{Bulgular ve yorumlar}

\section{Yunus Emre Enstitüsü B1 düzeyi ders kitabında bulunan yazma becerisi kazanımları}

Araştırmanın bu kısmında öncelikle ders kitabı bünyesinde yer alan yazma etkinliklerinin kapsadığı 33 adet kazanım ünitelere göre tasnif edilerek tablo haline getirilmiştir.

Tablo 1. Yunus Emre Enstitüsü Türkçe Öğretimi Bı düzeyi ders kitabında yer alan yazma becerisi kazanımları

\begin{tabular}{|c|c|}
\hline Ünite & Kazanimlar \\
\hline Ünite 1 & $\begin{array}{l}\text { 1-Kişisel yorum bildiren ifade ve kalıpları kullanır } \\
\text { 2-Duygu ve düşüncelerini ifade eden kalıpları kullanır. } \\
\text { 3-Yaşadığı olayların ve deneyimlerin önemli noktalarını vurgulayarak metinler yazar. }\end{array}$ \\
\hline Ünite 2 & $\begin{array}{l}\text { 1-İlan, broşür, duyuru vs. metinleri hazırlar. } \\
\text { 2-Özgeçmiş yazar. } \\
\text { 3-Kitap ya da filmin konusunu ana hatlarılla anlar ve yorumlar. }\end{array}$ \\
\hline Ünite 3 & $\begin{array}{l}\text { 1-Araştırdı ğı bir konu hakkında elde ettiği bilgiyi ayrıntılarıyla yazar. 2-Kişisel yorum bildiren } \\
\text { ifade ve kalıpları kullanır. }\end{array}$ \\
\hline
\end{tabular}

\footnotetext{
Adres $\mid$ Address

RumeliDE Dil ve Edebiyat Araşttrmaları Dergisi $\quad$ RumeliDE Journal of Language and Literature Studies Osmanağa Mahallesi, Mürver Çiçeği Sokak, No:14/8 Osmanağa Mahallesi, Mürver Çiçeği Sokak, No:14/8

Kadıköy - İSTANBUL / TÜRKIYE 34714 Kadıköy - ISTANBUL / TURKEY 34714 e-posta: editor@rumelide.com e-mail: editor@rumelide.com,

tel: +90 505 7958124, +90 216773 o 616 phone: +90 505 7958124, +90 2167730616
} 


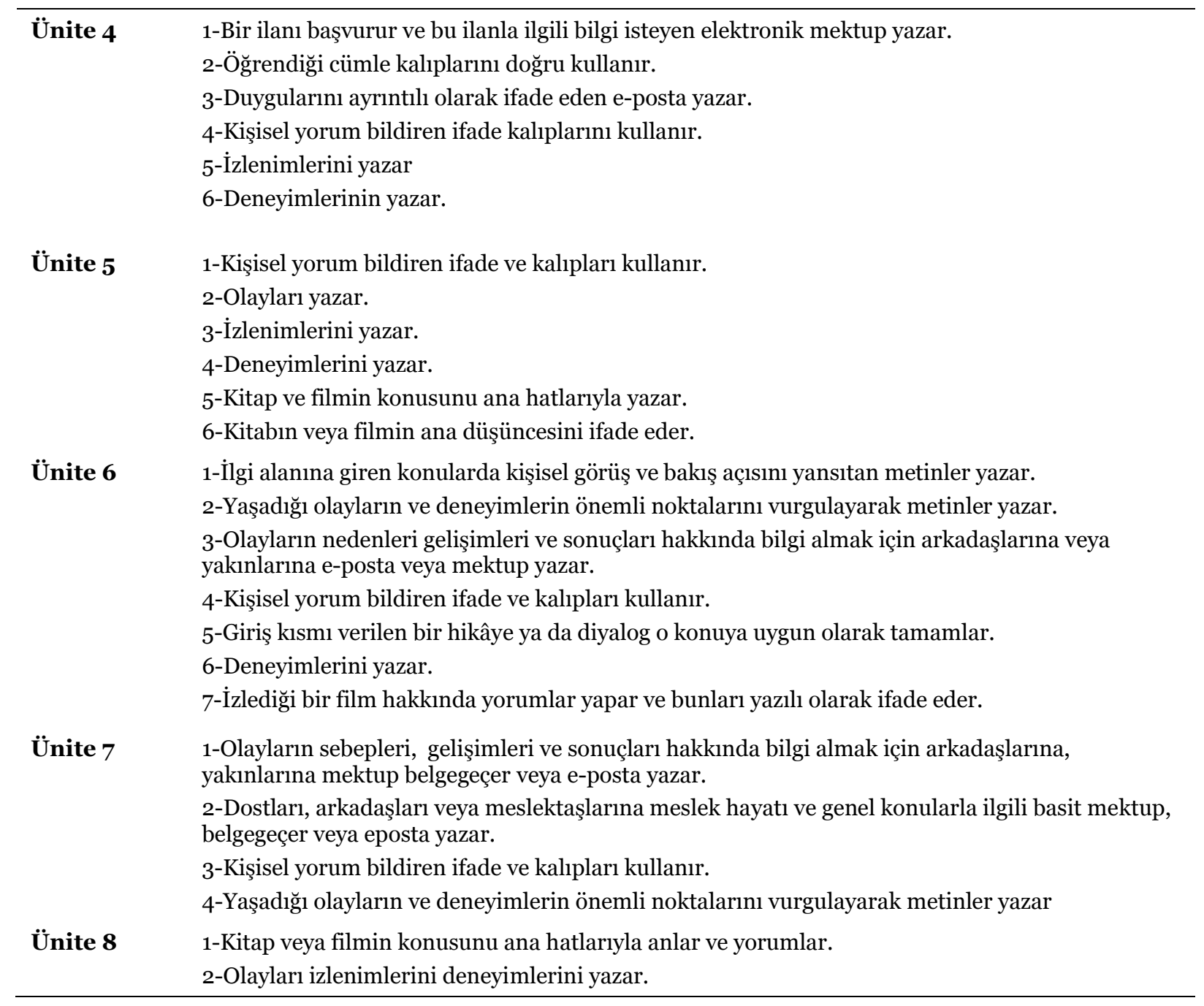

Yabancılara Türkçe öğretiminde kullanılan Yunus Emre Enstitüsü B1 düzeyi ders kitabında yazma becerisi için geliştirilen etkinliklerde farklı teknikler tercih edilmiştir. Bununla birlikte yukarda listelenen kazanımlar da sürecin ana omurgasını teşkil etmiştir. Yeniden oluşturma, açı uçlu sorularla yazma, boşluk doldurma, tema ekseninden metni devam ettirme, yeniden yazma, kurgulama gibi yazma yöntemleri materyal bünyesinde mevcuttur. Bu sayede yazma etkinliklerinde çeşitliliğin sağlandığı ve kazanımların detaylı şekilde gözetildiği söylenebilir.

\section{Yunus Emre Enstitüsü Bı düzeyi ders kitabında bulunan yazma becerisi kazanımları ve tematik olarak sınıflandırılması}

Avrupa Ortak Dil Başvuru Metni kapsamında öğrencinin hedef dili kendi ihtiyaçlarını karşılayabilecek düzeyde kullanması tüm dil eğitimcileri tarafından benimsenen bir gerçektir. Öğrencilerin yabancı dil öğrenmedeki temel amaçları aldıkları dil eğitiminin temasını da oluşturan ana omurga niteliğindedir. Avrupa Ortak Dil Başvuru Metni’ne göre (2007: 32) B1 düzeyinde yazma becerisi için öğrencinin ilgi alanında ya da kendini ilgilendiren konular ekseninde basit, kendi içinde bağlantılı metinler; deneyim ve izlenimlerinin içeren mektuplar yazabileceğini belirtmiştir. Çalışmanın bu kısmında ifade edilen Avrupa Ortak Dil Başvuru Metni gözetilerek Yunus Emre Enstitüsü B1 düzeyi ders kitabında yazma becerisi için belirtilen kazanımları değerlendirilerek tematik olarak sınıflandırılmaya çalışılmıştır. Ders

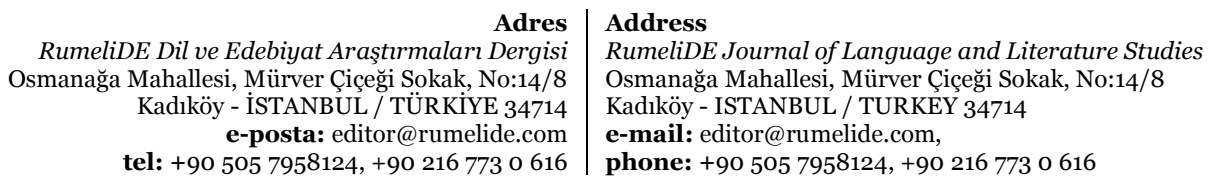


kitabı bünyesinde yer alan kazanımlar için yaratıcılık, ifade gücü, işlevsellik, kalıp bilgi olmak üzere 4 ana başlık belirlenmiştir.

Yaratıcılık başlığı altında temalandırılan kazanımlar öğrencinin kendi hayal gücü ve üretkenliği ile oluşturabileceği metinleri muhteva etmektedir. İfade gücü başlığı altında toplanan kazanımlar ise öğrencinin gözlemleri, kendi çıkarımları ekseninde oluşturduğu metinlere yönelik kazanımlar olarak tasnif edilmiştir. İşlevsel kullanım başlığında toplanan kazanımlar ise öğrencinin hedef dilde temel ihtiyaçlarını, kamu kurum ve kuruluşlarına yapacağı başvuruları gözeten kazanımları bir araya getirmiştir. Kalıp bilgi başlı̆̆ ise öğrencilerin hedef dilde bürokratik işlemler için kullanılan belge ve formları doldurabilmelerini gözeten kazanımlar olarak tasnif edilmiştir. Bu kapsamda ilgili sinıflandırmayı içeren tablo aşağıdadır.

Tablo 2. Yunus Emre Enstitüsü Türkçe Öğretimi B1 düzeyi ders kitabında yer alan yazma becerisi kazanımlarının Tematik Sinıflandırılması

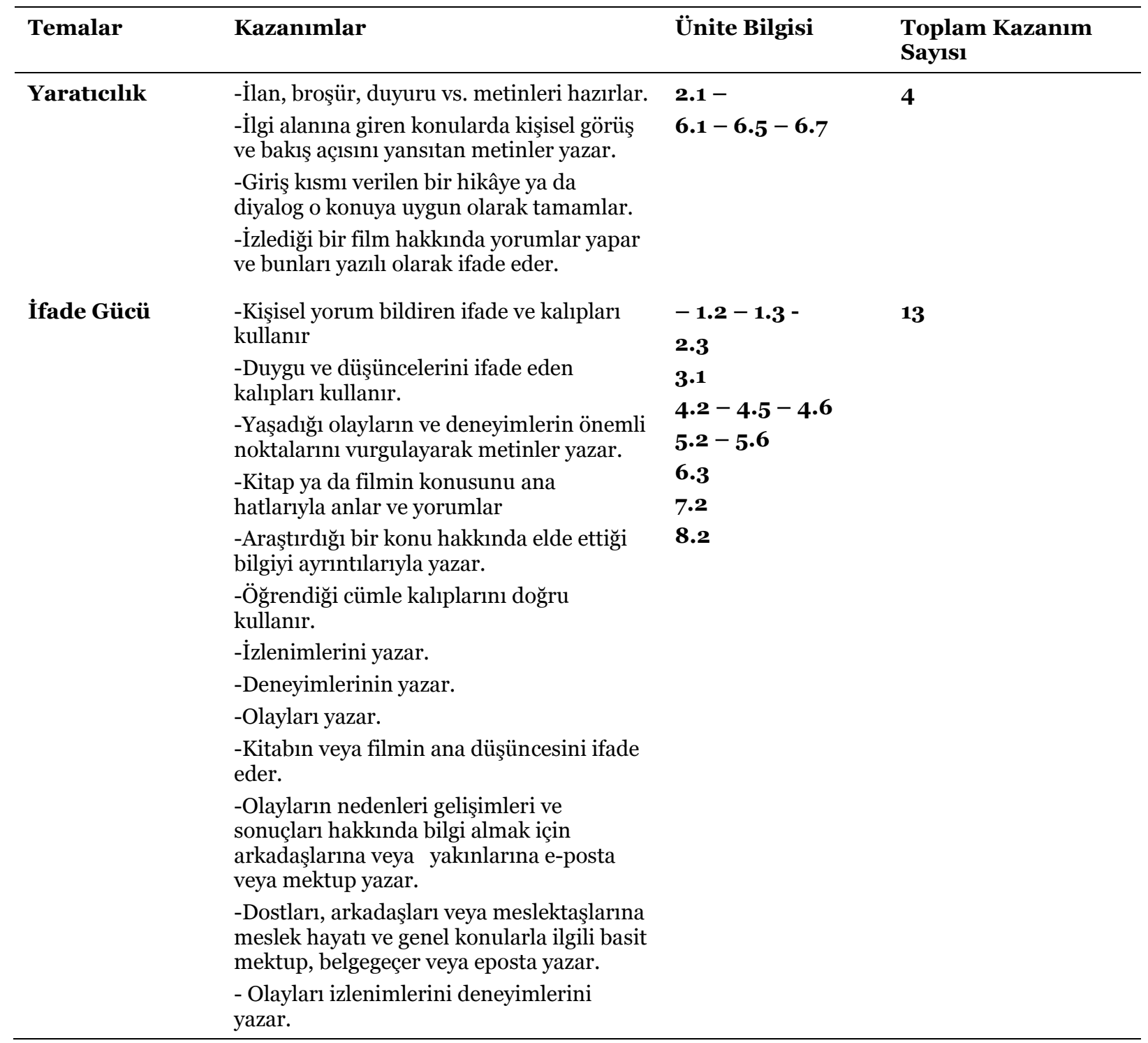

RumeliDE Dil ve Edebiyat Araşttrmaları Dergisi Osmanağa Mahallesi, Mürver Ciçeği Sokak, No:14/8 Kadıköy - İSTANBUL / TÜRKIYE 34714 e-posta: editor@rumelide.com tel: +90 505 7958124, +90 2167730616
Address

RumeliDE Journal of Language and Literature Studies Osmanağa Mahallesi, Mürver Çiçeği Sokak, No:14/8

Kadıköy - ISTANBUL / TURKEY 34714

e-mail: editor@rumelide.com,

phone: +90 505 7958124, +90 2167730616 


\begin{tabular}{llll}
\hline İşlevsel & -Bir ilanı başvurur ve bu ilanla ilgili bilgi & $\mathbf{4 . 1}-\mathbf{4 . 3}$ & $\mathbf{2}$ \\
Kullanım & $\begin{array}{l}\text { isteyen elektronik mektup yazar. } \\
\text {-Duygularını ayrıntılı olarak ifade eden e- } \\
\text { posta yazar. }\end{array}$ & & \\
Kalıp Bilgiler & -Özgeçmiş yazar. & $\mathbf{2 . 2}$ & $\mathbf{1}$ \\
\hline
\end{tabular}

Yunus Emre Enstitüsü B1 düzeyi ders kitabında yazma becerisi etkinliklerinin incelenmesine yönelik tablo aşağıdadır.

Tablo 3. Yunus Emre Enstitüsü Türkçe Öğretimi B1 düzeyi ders kitabında yer alan yazma becerisi etkinliklere yönelik değerlendirme

\begin{tabular}{|c|c|c|c|c|c|}
\hline & İçerik & Yöntem & Kazanım & $\begin{array}{l}\text { Temel Becerilerle } \\
\text { Bütünlük }\end{array}$ & AODBM uygunluk \\
\hline $\begin{array}{l}\text { ÜNITTE } \\
\mathbf{1}\end{array}$ & $\begin{array}{l}\text {-Yeniden } \\
\text { Yazalım (S.13) } \\
\text {-Ne Yaparsınız } \\
\text { (S.17) } \\
\text {-Hangi Görüşe } \\
\text { Katılıyorsunuz. } \\
\text { (S.23) }\end{array}$ & $\begin{array}{l}\text {-Cümle } \\
\text { Oluşturma } \\
\text {-Cümle } \\
\text { tamamlama } \\
\text {-Metin } \\
\text { Oluşturma }\end{array}$ & $\begin{array}{l}1.1 \\
1.2 \\
1.3\end{array}$ & $\begin{array}{l}\text { Boşluk doldurma } \\
\text { etkinlikleri, kısa } \\
\text { cümleler ve konuşma } \\
\text { etkinlikleri ile yazma } \\
\text { becerisi etkinliği } \\
\text { desteklenmiştir. }\end{array}$ & $\begin{array}{l}\text { Öğrencinin ilgi alanları le ilgili } \\
\text { basit metinlerin yazımı esas } \\
\text { alınmıştır. Öğrencinin } \\
\text { görüşlerini, deneyimlerini } \\
\text { aktarması amaçlanmıştır. }\end{array}$ \\
\hline $\begin{array}{l}\text { ÜNITTE } \\
2\end{array}$ & $\begin{array}{l}\text {-Halk } \\
\text { Ozanı.(S.30) } \\
\text {-Özgeçmiş } \\
\text { (S.40) } \\
\text {-En İyi film } \\
\text { (S.44) }\end{array}$ & $\begin{array}{l}\text {-Alıntılama } \\
\text {-Kısa metin } \\
\text { düzenleme }\end{array}$ & $\begin{array}{l}2.1 \\
2.2 \\
2.3\end{array}$ & $\begin{array}{l}\text { Okuma ve konuşma } \\
\text { becerisi } \\
\text { etkinliklerinde yer } \\
\text { alan boşluk } \\
\text { doldurma, yeniden } \\
\text { oluşturma } \\
\text { alıştırmaları ile } \\
\text { yazma becerisi } \\
\text { etkinliği hem konu } \\
\text { hem de içerik } \\
\text { açısindan } \\
\text { desteklenmiştir. }\end{array}$ & $\begin{array}{l}\text { AODBM kapsamında öğrencinin } \\
\text { özgeçmiş hazırlama, kurumlara } \\
\text { başvuruda bulanabilme } \\
\text { yetkinlikleri özetilmiş ve bu } \\
\text { durumların yazılı olarak } \\
\text { yapılmasına özen gösterilmiştir. }\end{array}$ \\
\hline $\begin{array}{l}\text { ÜNİTE } \\
\mathbf{3}\end{array}$ & $\begin{array}{l}\text {-Araştıralım } \\
\text { (S.56) } \\
\text {-Dilin Önemi } \\
\text { (S.61 }\end{array}$ & $\begin{array}{l}\text {-Metin } \\
\text { yazma } \\
\text {-Metin } \\
\text { yazma }\end{array}$ & $\begin{array}{l}3.1 \\
3.2\end{array}$ & $\begin{array}{l}\text { Ünite bünyesindeki } \\
\text { yazma etkinlikleri } \\
\text { özellikle okuma } \\
\text { becerisi alıştırmaları } \\
\text { ile bütünlük } \\
\text { gösterdiği } \\
\text { gözlemlenmiştir. } \\
\text { Ayrıca yazma becerisi } \\
\text { açısından kelime } \\
\text { haznesini destekleyici } \\
\text { alıştırmalar } \\
\text { mevcuttur. }\end{array}$ & $\begin{array}{l}\text { Öğrencinin ilgi alanı içinde yer } \\
\text { alan bir konu ile ilgili yazılar } \\
\text { yazmasına yönelik yazma } \\
\text { becerisi etkinlikleri öne } \\
\text { çlkmaktadır. Bu sayede öğrenci } \\
\text { yazma becerisini işlevsel olarak } \\
\text { kullanabilme yetisi kazanabilir. }\end{array}$ \\
\hline $\begin{array}{l}\text { ÜNITTE } \\
4\end{array}$ & $\begin{array}{l}\text {-Kursa Kayıt } \\
\text { (S.77) } \\
\text {-Hakkımı } \\
\text { Arıyorum } \\
\text { (S.81) } \\
\text {-Karikatür } \\
\text { (S.87) }\end{array}$ & $\begin{array}{l}\text {-Başvuru } \\
\text { metni } \\
\text { oluşturma } \\
\text {-Metin } \\
\text { oluşturma } \\
\text {-Tasvir } \\
\text { cümlesi } \\
\text { yazma }\end{array}$ & $\begin{array}{l}4.1 \\
4.2 \\
4.3 \\
4.4 \\
4.5 \\
4.6\end{array}$ & $\begin{array}{l}\text { Dili işlevsel olarak } \\
\text { kullanma ve } \\
\text { öğrencinin temel } \\
\text { ihtiyaçlarını giderme } \\
\text { gayesi ekseninde } \\
\text { şekillenene ünitede } \\
\text { okuma, konuşma } \\
\text { becerisi etkinlikleri } \\
\text { ile yazma becerisi } \\
\text { etkinlikleri içerik ve } \\
\text { konu bakımından } \\
\text { birbirini tamamlayıcı } \\
\text { niteliktedir. }\end{array}$ & $\begin{array}{l}\text { Ünite bünyesinde yer alan yazma } \\
\text { etkinlikleri öğrencinin kurum ve } \\
\text { kuruluşlara yapacağı başvurular } \\
\text { kapsamında hazırlanmış olup } \\
\text { ögrencinin temel gereksinimleri } \\
\text { açısından dili kullanmasını } \\
\text { hedeflemektedir. }\end{array}$ \\
\hline
\end{tabular}




\begin{tabular}{|c|c|c|c|c|c|}
\hline $\begin{array}{l}\text { ÜNİTE } \\
5\end{array}$ & $\begin{array}{l}\text {-Engelleri } \\
\text { Aşalım (S.97) } \\
\text {-En Sevdiğim } \\
\text { Film (S.100) } \\
\text {-Engeller } \\
\text { Nerede (S.105) }\end{array}$ & $\begin{array}{l}\text {-Metin } \\
\text { Oluşturma } \\
\text {-Metin } \\
\text { Oluşturma }\end{array}$ & $\begin{array}{l}5.1 \\
5.2 \\
5 \cdot 3 \\
5 \cdot 4 \\
5.5 \\
5.6\end{array}$ & $\begin{array}{l}\text { Sosyal sorumluluk } \\
\text { teması altında } \\
\text { şekillendirilen yazma } \\
\text { etkinlikleri diğer dil } \\
\text { becerisi etkinlik ve } \\
\text { alıştırmaları ile } \\
\text { bütünlük } \\
\text { sağlamaktadır. }\end{array}$ & $\begin{array}{l}\text { Öğrencinin ilgi duyduğu bir } \\
\text { alanda temel ifadeler ekseninde } \\
\text { kendini ifade etmesi } \\
\text { amaçlanmıştır. Ancak “En } \\
\text { sevdiğim film” isimli yazma } \\
\text { becerisi etkinliğinin derin } \\
\text { yorumlar gerektirmesi sebebi ile } \\
\text { seviyenin biraz üzerinde olduğu } \\
\text { düşünülmektedir. }\end{array}$ \\
\hline $\begin{array}{l}\text { ÜNİTE } \\
6\end{array}$ & $\begin{array}{l}\text { Satıyorum } \\
\text { (S.118) } \\
\text { Tamamlayalım } \\
\text { (S.121) } \\
\text {-Çizgi } \\
\text { Kahramanlar } \\
\text { (S.122) }\end{array}$ & $\begin{array}{l}\text {-Metin } \\
\text { Oluşturma } \\
\text {-Metin } \\
\text { tamamlama }\end{array}$ & $\begin{array}{l}6.1 \\
6.2 \\
6.3 \\
6.4 \\
6.5 \\
6.6 \\
6.7\end{array}$ & $\begin{array}{l}\text { Ünite bünyesinde yer } \\
\text { alan etkinlikler konu } \\
\text { bakımından alışveriş, } \\
\text { film izleme gibi farklı } \\
\text { başlılar altında } \\
\text { yapılandırılmıştır. Bu } \\
\text { sebeple içerik olarak } \\
\text { etkinlikler } \\
\text { bütünleyici } \\
\text { niteliklere sahip } \\
\text { değildir. }\end{array}$ & $\begin{array}{l}\text { Ünite bünyesinde yer alan yazma } \\
\text { becerisi etkinlikleri kültürel } \\
\text { kodlar dikkat çekmektedir. } \\
\text { Ayrıca hedef dili fonksiyonel } \\
\text { olarak kullandırmayı özendiren } \\
\text { "Satıyorum" isimli yazma } \\
\text { etkinliği AODBM B1 kazanımları } \\
\text { açsından uygundur. }\end{array}$ \\
\hline $\begin{array}{l}\text { ÜNİTE } \\
7\end{array}$ & $\begin{array}{l}\text {-Davet } \\
\text { Mektubu } \\
\text { (S.136) } \\
\text {-Bayraminız } \\
\text { Kutlu Olsun } \\
\text { (S.138) } \\
\text {-Düğün } \\
\text { Nasıldı (S.143) }\end{array}$ & $\begin{array}{l}\text {-Metin } \\
\text { Oluşturma }\end{array}$ & $\begin{array}{l}7.1 \\
7.2 \\
7.3 \\
7.4\end{array}$ & $\begin{array}{l}\text { Alıştırma ve } \\
\text { etkinlikler dil becerisi } \\
\text { etkinliklerini } \\
\text { bütünleyici } \\
\text { niteliklere sahiptir. } \\
\text { Açı uçlu sorular ile } \\
\text { hem okuma becerisi } \\
\text { etkinlileri hem } \\
\text { konuşma becerisi } \\
\text { etkinlikleri yazma } \\
\text { becerisi etkinlikleri } \\
\text { ile konu ve tama } \\
\text { bakımından } \\
\text { ilintilendirilmiştir. }\end{array}$ & $\begin{array}{l}\text { Kutlama teması etrafinda } \\
\text { şekillendirilen bu ünite AODBM } \\
\text { B1 kazanımları açsından } \\
\text { uygundur. }\end{array}$ \\
\hline $\begin{array}{l}\text { ÜNİTE } \\
\mathbf{8}\end{array}$ & $\begin{array}{l}\text {-Başyapıt } \\
\text { (S.153) } \\
\text {-Kişisel } \\
\text { Başarılar } \\
\text { (S.164) }\end{array}$ & $\begin{array}{l}\text {-Metin } \\
\text { oluşturma }\end{array}$ & $\begin{array}{l}8.1 \\
8.2\end{array}$ & $\begin{array}{l}\text { Ünite bünyesinde ye } \\
\text { alan boşluk } \\
\text { doldurma etkinlikleri } \\
\text { ve eşleştirme } \\
\text { etkinlikleri ile okuma } \\
\text { becerisi, } \\
\text { Konuşma becerisi } \\
\text { yazma becerisi ile } \\
\text { bütünlük içinde } \\
\text { olduğu } \\
\text { gözlemlenmiştir. }\end{array}$ & $\begin{array}{l}\text { Öğrenciyi mümkün olduğunca } \\
\text { dili serbest kullanmaya } \\
\text { özendirici etkinlikler öne } \\
\text { çımaktadır. Öğrencinin ilgi } \\
\text { alanında yazmasını özendirici } \\
\text { etkinlikler AODBM B1 } \\
\text { kazanımlarının gözetildiğini } \\
\text { göstermektedir. }\end{array}$ \\
\hline
\end{tabular}

Yunus Emre Enstitüsü B1 düzeyi ders kitabında 1.ünitede yer alan yazma becerisi etkinlikleri öğrencinin belirli konularda kişisel görüş ve deneyimlerini yazılı olarak ifade edebilmelerini amaçlamıştır. Yazma becerisi ile diğer temel dil becerileri boşluk doldurma etkinlikleri, cümle tamamlama alıştırmaları ile bir bütün hainde öğrenciye sunulmuştur. Avrupa Ortak Dil Başvuru Metni yazma becerisi B1 düzeyinde belirtilen kazanımlar da gözetilmiştir. Bu kapsamda öğrencinin kendi düşünce ve fikirlerini ifade etmesine yönelik etkinlikler geliştirilmiştir. 2.ünitede yer alan yazma becerisi etkinliklerinde kültürel kodların yoğunluğu dikkat çekmektedir. Ayrıca ünitenin genel hedefleri içinde yer alan duyuru, broşür metni oluşturma, özgeçmiş oluşturma gibi yazma becerisi kazanımlarının gözetildiği saptanmıştır. Böylece öğrencinin dili işlevsel olarak kullanması ve temel gereksinimlerini karşılaması da önemsenmiştir. Dilbilgisi yapılarında ekler ile yeniden oluşturma alıştırmaları yazma becerisini destekleyici niteliktedir. Konuşma ve okuma becerileri kapsamında

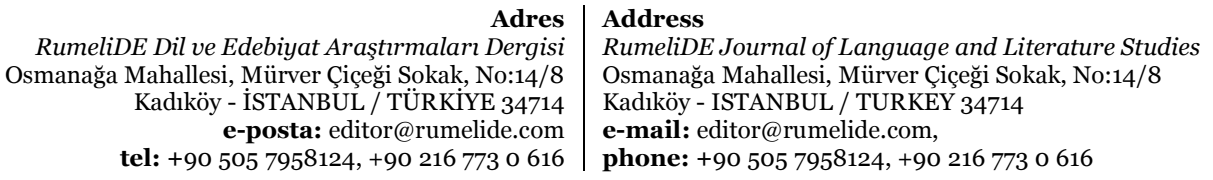


hazırlanan alıştırmalar hem içerik hem de konu bakımından yazma becerisini destekleyici niteliktedir. İş bulma teması etrafında öz geçmiş hazırlama etkinliği hem yazma hem okuma becerisini bütün haline getirmektedir.

Yunus Emre Enstitüsü B1 düzeyi ders kitabında 3.ünitede yer alan yazma becerisi etkinlikleri öğrencinin dili işlevsel olarak kullanması ve ilgi alanı içine giren konularda yazılar yazabilmesini öncelemiştir. Kültürel kodların nispeten az olduğu yazma becerisi etkinlikleri kılavuz kitapta yer alan "Araştırdiğı bir konu hakkında elde ettiği bilgiyi ayrıntılarıyla yazar." Kazanımını doğrudan karşılayan niteliklere sahip değildir. Okuma becerisi etkinlikleri bünyesinde yer alan alıştırmalar ile kelime haznesi geliştirilmek istenmiş ve yazma becerisi etkinliklerinde bu kelimelerin kullanılması istenmiştir. 4.ünitede yer alan yazma etkinlikleri öğrencinin kısa cümleler ve metinler oluşturması amacı ekseninde dizayn edilmiştir. Okuma ve konuşma becerisi etkinlikleri ile yazma becerisi etkinlikleri içerik ve konu bakımından birbirini tamamlamaktadır. Ayrıca kelime haznesini geliştirmek amacıyla yapılan uygun ekleri kelimelere getirme alıştırmaları öğrencinin kelime haznesini geliştirmeyi amaçlamaktadır. Ancak ünite bünyesinde bulunan "İzlenimlerini ve deneyimlerini yazar" kazanımı yazma etkinlikleri açısından kapsam olarak zayıf kaldığı gözlemlenmiştir.

Yunus Emre Enstitüsü B1 düzeyi ders kitabında 5.ünitesinde bedensel engelli insanlar özelinde sosyal sorumluluk teması işlenmiştir. Dört temel dil becerisi için hazırlanan içerik, etkinlik ve alıştırmalar birbirini bütünleyici niteliktedir. Konu ve içerik anlamında engelli insanlar için duyarlı olma teması üzerinde durulmuştur. Yazma becerisi etkinlikleri de ifade edilen hassasiyetler ekseninde şekillendirilmiştir. Ancak "En sevdiğim film" isimli etkinlik kapsamlı yorum ve uzun cümleler kurmayı gerektirdiği için B1 seviyesinin biraz üzerinde olduğu söylenebilir. "Olayları, izlenimlerini, deneyimlerini yazar.” kazanımı ilgili etkinlik için temel seviye düzeyinde kaldığı söylenebilir. Ünite özelinde evrensel değerler öne çıkarken yazma becerisi etkinlikleri de bu bağlamda şekillendirilmiştir. 6.ünitede ise yazma becerisi etkinlikleri Türk yemek kültürü ile öğrencilerin mensubu oldukları ülkelerin yemek kültürlerini karşılaştırmaktadır. Bu bakımdan kültürel kodların yoğun olduğu gözlemlenmiştir. Ayrıca dili fonksiyonel olarak kullanmak ve temel gereksinimleri karşılamak maksadı ile "Satıyorum" isimli yazma becerisi etkinliği düzenlenmiştir. Metin tamamlama etkinliği ile öğrencinin yaratıcı tarafı harekete geçirilmeye çalışıldığı gözlemlenmiştir. Ünite bünyesinde "Yaşadığı olayların ve deneyimlerin önemli noktalarını vurgulayarak metinler yazar" kazanımı olsa da yazma becerisi etkinliklerin de bu kazanımı gözetme bakımından yetersiz olduğu saptanmıştır. Daha çok "Olayların nedenleri gelişimleri ve sonuçları hakkında bilgi almak için arkadaşlarına veya yakınlarına e-posta veya mektup yazar" ve "İzlediği bir film hakkında yorumlar yapar ve bunlar yazıl olarak ifade eder" kazanımlarını gözeten yazma becerisi etkinlikleri düzenlenmiştir.

Yunus Emre Enstitüsü B1 düzeyi ders kitabında 7.ünitesinde yer alan okuma ve konuşma becerisine yönelik eşleştirme etkinlikleri ile açık uçlu sorular yazma becerisi etkinliklerinin teması ile doğrudan ilintili olduğu saptanmıştır. Yazma konusu için ön hazırlık mahiyetindedir. Ancak ünite bünyesinde yer alan "Kişisel yorum bildiren ifade ve kalpları kullanı" kazanımının yazma becerisi etkinlikleri bünyesinde kalıp ifadeler ve sınırları belirli yazma etkinliklerinin ağırıkta olması sebebiyle gölgede kaldığı düşünülmektedir. Ayrıca ünite bünyesinde yazma becerisi etkinliklerde ülkeler bazında düğünlerin kıyaslandığı görülmekte olup kültürel kodların da gözetildiği saptanmıştır. 8.ünitede yer alan yazma becerisi etkinlikleri öğrenciyi ilgi alanında yazmaya özendirici nitelikler taşımaktadır. $\mathrm{Bu}$ bakımdan ünite kapsamı içinde yer alan "Kitap veya filmin konusunu ana hatlarıla anlar ve yorumlar; olaylar izlenimlerini deneyimlerini yazar" kazanımlarını yansıtan yazma becerisi etkinliklerinin ünite de yer aldı̆̆ı tespit edilmiştir. İzlenen film, okunan bir hikâyenin devam

\begin{tabular}{r|l} 
Adres & Address \\
RumeliDE Dil ve Edebiyat Arastrmalart Dergisi & RumeliDE
\end{tabular} Osmanağa Kadıköy - ISTANBUL / TÜRKIYE 34714 e-posta: editor@rumelide.com tel: +90 505 7958124, +90 2167730616 Osmanağa Mahallesi, Mürver Çiçeği Sokak, No:14/8

Kadıköy - ISTANBUL / TURKEY 34714

e-mail: editor@rumelide.com,

phone: +90 5057958124 , +90 216773 o 616 
ettirilmesini gözeten alıştırma ve etkinlikler yazma becerisi etkinlikleri ile ilişkilendirilmiştir. Ünite bünyesinde yer alan yazma becerisi etkinlikleri öğrencinin dili bağımsız olarak kullanmaya özendirmektedir. Bu yönü ile kolaydan zora doğru ilerleyen yazma becerisi etkinlikleri son bölümde tam anlamı ile öğrencinin bilgi, beceri ve tecrübelerini yorum gücü ile birleştirmeyi amaçlamıştır. Ayrıca yer yer kültürel kodlar öne çıkmış öğrencinin kendi ülkesinde benzer durumların nasıl karşılandı̆̆ını yazılı olarak beyan etmesi istenmiştir.

\section{Tartışma, sonuç ve öneriler}

Yazma becerisi hem yabancı dil eğitimi hem de ana dili eğitimi açısından oldukça ayrıntılı ve geliştirilmesi zorlu bir süreçtir. Yazma becerisine yönelik yazma süreci (Tiryaki, 2013), yazma becerisinde kullanılacak teknoloji tabanlı uygulamalar (Baş ve Turhan, 2013), yazma kaygısı (İşcan, 2015; Şen ve Boylu, 2017), yazma becerisinin oyunlarla ve çağrışım tekniği ile geliştirilmesi (Kalfa, 2014; Kara ve Çiftçi, 2019), yazım ve noktalama(Genç, 2017), sosyal medya kullanımı ve yazma ilişkisi (Çangal,2020), yazma etkinlikleri ve kullanılan yazma yöntemleri üzerine yapılan değerlendirmeler (Yılmaz, 2014) öne çımaktadır.

$\mathrm{Bu}$ araştırmada Yunus Emre Enstitüsü B1 düzeyi ders kitabında yer alan yazma becerisi etkinlikleri kazanımlar ve CEFR çerçevesinde incelenmiştir. Ders materyalinde yer alan etkinlikler temel dil becerilerini bütünleyici niteliktedir. Özellikle okuma becerisi etkinlikleri ile yazma becerisi etkinlikleri içerik ve konu bakımından bir bütünlük oluşturmaktadır. Açı uçlu sorular ve dil bilgisi alıştırmaları yazma becerisi etkinlikleri için ön hazırlık mahiyetinde olduğu söylenebilir. Okuma becerisi ve yazma becerisi etkinlikleri konular bakımından eşgüdümlü olarak yapılandırıldığı dikkat çekmektedir. Nicel olarak yazma becerisi etkinlikleri diğer beceri etkinliklerine göre arka planda kalsa da açık uçlu sorular ve alıştırmalar yazma becerisi etkinliklerini destekleyici niteliktedir. Yazma yöntemleri açısından genelde öğrenci doğrudan metin oluşturmaya ve metin tamamlamaya yönlendirilmiştir. Bu yönü ile kullanılan yazma yöntemlerinin çeşitlilik arz etmediği saptanmıştır.

Grafik 1. Yazma becerisi kazanımlarının sınıflandırılması

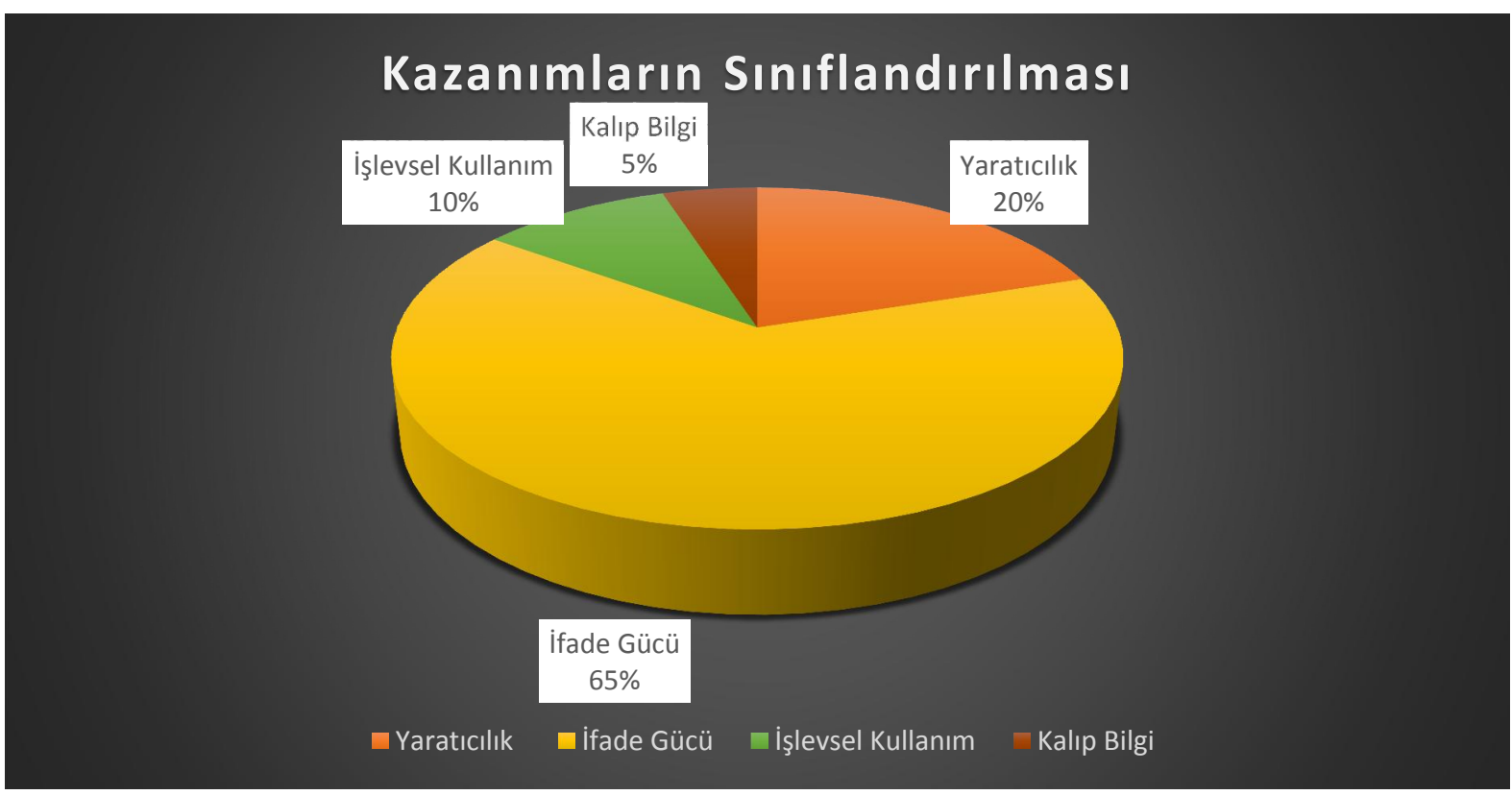

Adres

RumeliDE Dil ve Edebiyat Araştırmalar Dergisi Osmană̆a Mahallesi, Mürver Çiçeği Sokak, No:14/8 Kadıköy - İSTANBUL / TÜRKIYE 34714 e-posta: editor@rumelide.com tel: +90 $5057958124,+902167730616$
Address

RumeliDE Journal of Language and Literature Studies

Osmanağa Mahallesi, Mürver Çiçeği Sokak, No:14/8

Kadıköy - ISTANBUL / TURKEY 34714

e-mail: editor@rumelide.com,

phone: +90 5057958124, +90 2167730616 
Yazma becerisi etkinlikleri için B1 düzeyinde verilen kazanımlar temalandırılmıştır. Toplam 20 adet kazanım tespit edilmiş olup bu kazanımlar yaratıcılık, ifade gücü, işlevsel kullanım, kalıp bilgi başlıkları altında toplanmıştır. Yaratıcılık başlığı altında 4 kazanım, kalıp bilgi başlığı altında bir kazanım, işlevsel kullanım başlığında 2 kazanım, ifade gücü başlı̆̆ında ise 13 kazanım bulunduğu tespit edilmiştir. Grafik 1'de görüldüğü üzere ifade gücünü geliştirmeye yönelik kazanımlar ders materyalinde öne çıkarken kalıp bilgi ve işlevsel kullanım alanları ihmal edilmiştir. Bu kapsamda ifade gücünü geliştirmeye yönelik kazanım ve etkinlik sayısı diğer alanlara göre oldukça baskın düzeydedir. $\mathrm{Bu}$ çerçevede öğrencinin iletişim becerilerini yazma becerisi etkinlikleriyle de öncelenmiştir. Öğrencinin başından geçen bir olayı, izlediği bir filmi, tanık olduğu bir durumu kendi ifadeleri ile özgün bir şekilde yazılı olarak ifade etmesi; kalıp ifadeleri kullanabilmesi etkinliklerin gözettiği kazanımların başında gelmektedir. Ayrıca izlenen film ya da okunan bir metnini ana düşüncesini bulmaya yönelik yazma becerisi etkinlikleri de nicel anlamda ön plandadır. Bu etkinlik tasarımlarıyla öğrencinin yazılı ifade becerisi, cümle kurma özgüveni geliştirmeye yönelik olduğu söylenebilir. Ayrıca diğer beceri alanlarıla yazma becerisini bütünleştirmeye yönelik bir strateji takip edildiği görülmektedir.

Ünite bünyesinde verilen yazma becerisi kazanımları etkinlikler bünyesinde genel olarak gözetildiği saptanmıştır. "Kişisel yorum bildiren ifade ve kalıpları kullanır" kazanımı 6 farklı ünite kapsamında yer almış; bu yönü ile ders materyalinde en fazla gözetilen kazanım olarak tespit edilmiştir. "İzlenimlerini yazar" kazanımı 2, "deneyimlerinin yazar" kazanımı 2, "kitap ya da filmin konusunu ana hatlartyla anlar ve yorumlar" kazanımı 2 kez üniteler bünyesinde gözetilmiştir. Buradan da anlaşılacağı üzere ders kitabı bünyesinde yer alan yazma becerisi etkinlikleri öğrencinin yorum ve ifade gücünü geliştirmeyi amaçlamaktadır.

Avrupa Ortak Dil Başvuru Metni B1 düzeyi yazma becerisi kazanımı ekseninde yazma becerisi etkinliklerinin öğrencinin ilgi alanı ile ilişkilendirilmesine özen gösterilmiştir. Ayrıca yazma becerisi etkinlikleri kapsamına dilin işlevsel kullanımı için resmi kurumlara başvuruda doldurulacak evraklar ile başvuru metni içeren etkinlikler yapılmış; ancak ncelik anamda diğer etkinlik içeriklerine göre geri planda kalmıştır.

Genel çerçevede B1 düzeyi öğrencilerin dili işlevsel kullanması, yazma becerisi özelinde öğrencinin kendini rahat bir şekilde ifade etmesi öncelenmiş; kazanımlar ve etkinlikler de bu yönde yapılandırılmıştır.

\section{Öneriler}

- Yazma becerisi etkinlikleri açısından kullanılan yöntemlerin zenginleştirilmesi, bir yönerge etrafında ilerlemesi yazma becerisine yönelik önyargıyı azaltacaktır.

- Yazma becerisi etkinlikleri için hazırlanan kazanımların ifade gücü yanında dili işlevsel olarak da kullandırmaya, kurum ve kuruluşlar için yazılar yazabilmeye yönlendirmesi öğrenen ihtiyaçları açısından faydalı olacaktır.

- Yazma etkinlikleri kolaydan zora doğru ilkesi gözetilerek ilerlemelidir. Bu kapsamda cümle, paragraf, metin yazdırmaya yönelik sıralama sık tekrar edilmelebilir

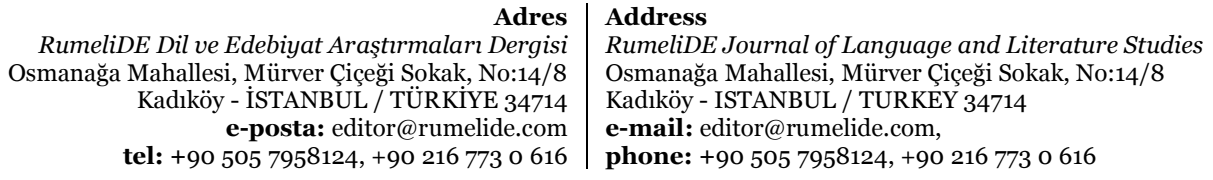

tel: $+905057958124,+902167730616$ 


\section{Kaynakça}

Açık, F. (2008). Türkiye'de yabancılara Türkçe öğretilirken karşılaşllan sorunlar ve çözüm önerileri. Doğu Akdeniz Üniversitesi Eğitim Fakültesi Türkçe Eğitimi Bölümü. Uluslararası Türkçe Ĕğitimi ve Öğretimi Sempozyumu.

Aksan, D. 1977. Her Yönüyle Dil, Ana Çizgileriyle Dilbilim I. Ankara: TDK.

Akyol, H. (2006) Türkçe Öğretim Yöntemleri, Kök: Ankara.

Altunışık, R., Coşkun, R., Bayraktaroğlu, S., \& Yıldırım, E. (2010). Sosyal Bilimlerde Araştırma Yöntemleri SPSS Uygulamalı (6. Baskı).Sakarya:Sakarya.

Asutay, H. (2003) Yabancı Dil Öğretiminde Kültür Bağlamı ve Öteki Dile, Ankara Üniversitesi (TÖMER) Dil Dergisi, 118. Ankara, Ankara Üniversitesi, s.26-29

Baş, B., \& Turhan, O. (2017). Yabancılara Türkçe Öğretiminde Yazma Becerisine Yönelik Web 2.o Araçları: Poll Everywhere Örneği. Mersin University Journal of the Faculty of Education, 13(3).

Çangal, Ö. (2020) Yabancılara Türkçe Öğretiminde Sosyal Medya Kullanımının Yazma Becerisine Etkisine Yönelik Öğrenici Görüşleri. Sosyal Bilimler Araşttrmaları Dergisi, (2020 Sonbahar Özel Sayı I/II), 52-61.

Çalık T (2001) Türkçe Ders Kitaplarını Biçim ve Tasarımı, Konu Alanı Ders Kitabı İnceleme Kılavuzu, Türkçe 1-8. Ankara: Nobel Yayın Dağıtımı.

Erdem, M. D., Gün, M., Şengül, M., \& Şimşek, R. (2015). Yabancılara Türkçe öğretiminde kullanılan okuma metinlerinin öğretim elemanlarınca diller için Avrupa ortak başvuru metni ve işlevsel metin özellikleri kapsamında değerlendirilmesi. Turkish Studies-International Periodical for the Languages, Literature and History of Turkish or Turkic, 10(3), 455-476.

Genç, H. N. (2017). Yabancı dil olarak Türkçe öğretiminde yazma eğitimi bağlamında yazım ve noktalama. Dil Dergisi, 168(2), 31-42.

Gün M, Akkaya A, Kara Ö T (2014) Yabancılara Türkçe Öğretimi Ders Kitaplarının Türkçe Öğretim Merkezlerinde Görev Yapan Öğretim Elemanları Açısından Değerlendirilmesi. - Turkish Studies - International Periodical For The Languages, Literature and History of Turkish or Turkic Volume 9/6 Spring,1-16, Ankara-Turkey

Hughey, J. B. (1983). Teaching ESL composition principles and techniques. Cambridge: Newbury House Publishers.

İşcan, A. (2015). Yabancı Dil Olarak Türkçe Öğretiminde Yazma Kaygısı Üzerine Bir İnceleme (Ürdün Üniversitesi Örneği). Dil ve Edebiyat Egitimi Dergisi, (14).

Kalfa, M. (2014). Yabancilara Türkçe Öğretiminde Temel Düzeydeki Öğrencilerin Eğitsel Oyunlarla Yazma Becerilerinin Geliştirilmesi. Hacettepe University Journal of Turkish Studies/HÜTAD Hacettepe Üniversitesi Türkiyat Arastirmalari Dergisi, (20).

Kaplan, M. (2012). Kültür ve Dil. İstanbul: Dergâh. Sayfa: 2

Karababa Z C (2009) Yabancı Dil Olarak Türkçenin Öğretimi ve Karşılaşılan Sorunlar, Ankara Üniversitesi Ĕ̆itim Bilimleri Dergisi, 265-277.

Kara M. (2010). Gazi Üniversitesi TÖMER Öğrencilerinin Türkçe Öğrenirken Karşlaştıkları Sorunlar ve Bunların Çözümüne Yönelik Öneriler. Türk Eğitim Bilimleri Dergisi, Yaz 2010, 8 (3), 661-696.

Kara, M., \& Çiftçi, E. (2019). Türkiye'deki Suriyeli Öğrencilere Türkçe Öğretiminde Çağrışım Tekniği Kullanımının Yazma Becerisine Etkisi. Journal of Turkish Educational Sciences, 17(1).

Okur, A., Keskin, F. (2013). Yabancılara Türkçe öğretiminde kültürel ögelerin aktarımı: İstanbul yabancılara Türkçe öğretim seti örneği. Turkish Studies,1619-1640.

Raimes, A. (1983). Tecniques in Teaching Writing. New York: Oxford University Press.

Stemler, S. (2001). An Overview of Content Analysis. Practical Assessment, Research \& Evaluation, 7(17).

Şen, Ü., \& Boylu, E. (2017). Türkçeyi Yabanci Dil Olarak Öğrenenlere Yönelik Yazma Kaygisi Ölçeğinin Geliştirilmesi. Uluslararası Türkçe Edebiyat Kültür Eğitim (TEKE) Dergisi, 6(2), 1122-1132.

Tiryaki, E. N. (2013). Yabancı dil olarak Türkçe öğretiminde yazma eğitimi. Ana Dili Eğitimi Dergisi, 1(1), 38-44.

Yllmaz, F. (2014). Yeni Hitit Yabancilar İçin Türkçe 2 Ders Kitabi Yazma Etkinlikleri Üzerine Bir İnceleme. Uluslararası Türk Eğitim Bilimleri Dergisi, 2014(2), 37-48.

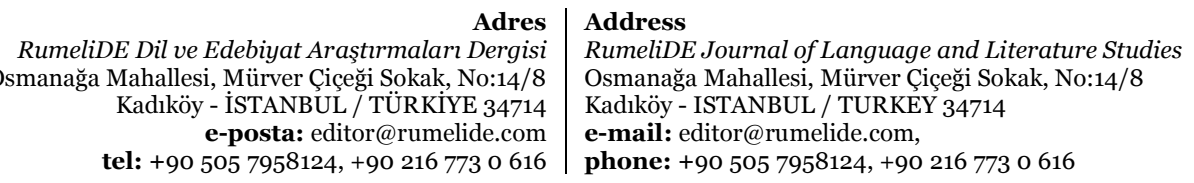

